\title{
Kajian Molekular Tarsius sp. Pada Gen Penyandi Cytochrome Oxidase Sub- unit 2 Mitokondria
}

\author{
The Molecular Study on Mitochondrial Cytochrome Oxidase 2(COX2) Gene of Tarsius sp. \\ Rini Widayanti ${ }^{1 *}$, Niken Satuti Nur Handayani ${ }^{2}$, dan I. Made Budiarsa ${ }^{3}$ \\ ${ }^{1}$ Bagian Biokimia Fakultas Kedokteran Hewan, Universitas Gadjah Mada, Yogyakarta \\ ${ }^{2}$ Fakultas Biologi, Universitas Gadjah Mada, Yogyakarta \\ ${ }^{3}$ Jurusan Biologi FMIPA, Universitas Tadulako, Sulawesi Tengah \\ E-mail: riniwida@yahoo.co.uk *Penulis untuk korespondensi
}

\begin{abstract}
Tarsius is an endemic species in Indonesia that is endangered. In-situ and ex-situ conservation of this species would yield better results if this genetic make up and diversity is determined. The objective of this ressearch was to study the specific genetic marker on COX2 gene of Tarsius sp. Sequencing of PCR product using primer $C O X 2 F$ and $C O X 2 R$ resulted in base sequence of 513 nts. Results of $C O X 2$ fragments sequencing were put on multiple alignment with other primates from Genbank with aid of software Clustal W, and were analyzed using MEGA program version 4.1. Eight different amino acid sites were found (amino acid no. 5, 6, 13, 14, 30, 35, 44 and 168). The genetic distance based on nucleotide $C O X 2$ calculated using Kimura 2-parameter model indicated that in the smallest genetic distance $0 \%$, biggest $6.8 \%$ and average $2.3 \%$. The phylogenetic tree using neighbor joining method based on the sequence of nucleotide and amino acid $C O X 2$ reveded differentiation among Tarsius from Lampung and Tarsius from Sulawesi, but could not be used to differentiate among $T$. dianae (from Central Sulawesi) and T. spectrum (from North Sulawesi).
\end{abstract}

Key words: Tarsius sp., COX2 gene, amino acid, mt-DNA sequens

\begin{abstract}
Abstrak
Tarsius adalah spesies endemik Indonesia yang keberadaannya terancampunah. Konservasi insitu dan $e x$-situ spesies ini akan menghasilkan hasil yang lebih baik ini keragaman genetik diketahui dengan pasti. Tujuan penelitian ini adalah untuk mempelajari penanda genetik spesifik pada gen COX2 Tarsius sp. Sekuensing produk PCR menggunakan primer COX2F dan COX2R menghasilkan urutan basa sepanjang 513 nt. Hasil sekuensing fragmen COX2 selanjutnya disejajarkan berganda dengan primata lain dari Genbank dengan bantuan perangkat lunak $C$ lustal $W$, dan dianalisis menggunakan versi program MEGA 4.1. Ditemukan delapan situs asam amino yang berbeda (asam amino no 5, 6, 13, 14, 30, 35, 44 dan 168). Jarak genetik berdasarkan nukleotida penyusun gen $C O X 2$ yang dihitung menggunakan metode Kimura 2-parameter menunjukkan bahwa jarak genetik terkecil adalah $0 \%$, terbesar $6,8 \%$ dan rata-rata 2,3\%. Pohon filogenetik menggunakan metode Neighbor joining berdasarkan urutan nukleotida dan asam amino COX2 dapat membedakan antara Tarsius dari Lampung dan Tarsius dari Sulawesi, tetapi tidak dapat digunakan untuk membedakan antara T. dianae (dari Sulawesi Tengah) dan T. spektrum (dari Sulawesi Utara).
\end{abstract}

Kata kunci: Tarsius sp., gen COX2, asam amino, sequen mt-DNA

Diterima: 05 Januari 2009, disetujui: 03 Maret 2010

\section{Pendahuluan}

Keanekaragaman spesies Tarsius berdasar perbedaan morfologi telah dilakukan oleh Musser dan Dagosto (1987) dan Groves (2001).
Mereka mengelompokkan Tarsius ke dalam 6 spesies, yaitu 5 spesies ( $T$. spectrum, $T$. dianae, T. pumilus, $T$. sangiriensis dan T. pelengensis) ada di Sulawesi dan 1 spesies ( $T$. bancanus) ada di Sumatera Selatan dan Kalimantan. 
Selanjutnya Shekelle dan Leksono (2004), melaporkan di Sulawesi saat ini telah ditemukan 16 populasi Tarsius (lima populasi sudah diberi nama oleh peneliti sebelumnya) yang kemungkinan dapat menjadi spesies tersendiri. Selanjutnya Shekelle et al., (2008) melaporkan adanya satu spesies baru di Sulawesi yang diberi nama $T$. tumpara.

Secara morfologi, antara T. bancanus dan Tarsius yang berasal dari Sulawesi dapat dibedakan dengan melihat panjang jumbai pada ekor dan dari lebar telinganya. Namun, di antara spesies-spesies Tarsius yang ada di Sulawesi sangat sulit untuk dibedakan. Mengingat status satwa liar dan langka ini populasinya semakin menurun, maka usaha pelestarian harus segera dilakukan secara serius, baik dilakukan secara in situ maupun ex situ.

Pengungkapan status genetik spesies Tarsius, satwa endemik dan langka ini merupakan landasan penentuan tujuan dan arah serta pengembangan kegiatan konservasi. Sampai saat ini, informasi tersebut masih terbatas sehingga perlu dilakukan penelitianpenelitian lanjutan untuk memecahkan masalah tersebut di atas, salah satunya melalui pendekatan molekular yang telah berkembang dengan pesat.

Sekuen DNA mitokondria dipilih sebagai penanda genetik karena berukuran relatif kecil (sekitar 16,5 kb) sehingga mudah untuk diamplifikasi, jumlah kopinya banyak sehingga mudah didapat dari sel, diturunkan dari induk betina (maternal) dan beberapa gen dalam mitokondria mutasinya lebih cepat daripada gen inti (Wertz, 2000). Menurut Majerus (1996), genom mitokondria mempunyai kecepatan evolusi 5-10 kali lebih cepat daripada genom inti. Daerah koding dan non koding DNA mitokondria sering digunakan untuk penelitian tentang evolusi dan hubungan kekerabatan antar spesies hewan oleh karena mutasinya tinggi.

Gen penyandi $C O X 2$ mempunyai ukuran $684 \mathrm{pb}$, terletak di antara gen penyandi $t \mathrm{RN}^{\mathrm{Asp}}$ (di sebelah kiri atau depan) dan gen penyandi $t \mathrm{RNA}^{\text {Lys }}$ (di sebelah kanan atau belakang) pada mt-DNA (Gambar 1) (Schmitz et al., 2002). Menurut Galina et al., (2003) pada gen penyandi COX 2 dan ND3 beberapa spesies hewan memiliki angka mutasi yang lebih besar dibandingkan dengan gen-gen penyandi lainnya di dalam DNA mitokondria.

Kajian molekuler gen penyandi $12 \operatorname{SrRNA}$ pada Tarsius telah dilakukan Shekelle (2003), karena homologinya tinggi, gen tersebut tidak dapat dijadikan penanda genetik. Demikian juga yang telah dilakukan Widayanti (2006), kajian molekuler daerah D-loop pada Tarsius tidak dapat dijadikan sebagai penanda genetik sedangkan pada gen $C y t b$ dapat digunakan sebagai penanda genetik walaupun hanya pada tingkat nukleotida saja (pada tingkat asam amino kurang mendukung) (Widayanti, 2007). Selanjutnya hasil penelitian Rini et al., (2010) pada sekuen gen ND3 ternyata tidak dapat untuk membedakan ketiga spesies $T$. bancanus, $T$. spectrum dan $T$. dianae. Untuk itu masih dibutuhkan penelitian lanjutan untuk mendapatkan penanda genetik-penanda genetik lain yang lebih spesifik untuk tiap-tiap spesies Tarsius.

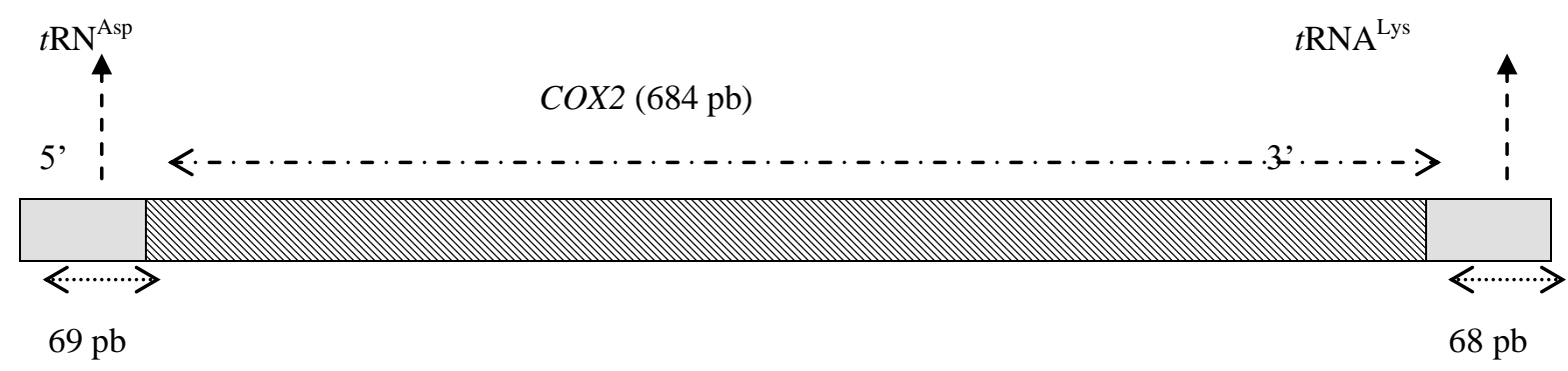

Gambar 1. Skema organisasi gen COX2 pada T. bancanus (Howell 1985 dan Schmitz et al., 2002). 


\section{Metode Penelitian}

\section{Koleksi Sampel}

Sampel darah Tarsius bancanus sebanyak 5 ekor diperoleh dari Lampung Sumatra Selatan, Tarsius spectrum sebanyak 1 ekor dari Sulawesi Utara dan 1 ekor Tarsius dianae dari Sulawesi Tengah.

\section{Isolasi DNA Total}

DNA total diekstraksi dari darah, dan potongan cuping telinga. Darah diambil dari pembuluh darah pada pangkal ekor, ditambah larutan EDTA $10 \%$ sebagai antikoagulan. Potongan telinga diambil dari Tarsius disimpan dalam alkohol $70 \%$.

Isolasi dan purifikasi DNA yang berasal dari contoh darah dan cuping telinga menggunakan DNA Isolation Kit (Qiagen).

Sampel DNA yang diperoleh disimpan pada suhu $-20^{\circ} \mathrm{C}$. DNA dilihat kualitasnya dengan dimigrasikan pada gel agarosa 1,2\% dengan menggunakan buffer 1xTBE (89 mM Tris, $89 \mathrm{mM}$ asam borat dan $2 \mathrm{mM}$ EDTA, $\mathrm{pH}$ 8,0 ). Pengamatan dilakukan dengan bantuan sinar UV ( $\lambda=300 \mathrm{~nm})$ setelah gel diwarnai dengan cyber save (Invitrogen).

\section{Desain Primer}

Desain primer oligonukleotida spesifik untuk gen $C O X 2$ dilakukan berdasakan database dari Genebank dengan menggunakan program Clustal W. Pasangan primer dipilih pada daerah yang polimorfismenya rendah (konserv). Selanjutnya primer oligonukleotida dianalisis menggunakan software Design Oligoprimer. Urutan basa primer untuk mengamplifikasi gen COX2 dapat dilihat pada Tabel 1.

\section{Amplifikasi Fragmen DNA dengan PCR}

DNA total hasil ekstraksi digunakan sebagai DNA cetakan untuk proses amplifikasi. Komposisi $50 \mu \mathrm{l}$ campuran pereaksi PCR terdiri dari 2,5 mM $\mathrm{MgCl}_{2}, 10 \mathrm{mM}$ dNTPs, 100-300 ng DNA cetakan, 20-100 pmol masing-masing primer dan $2 \mathrm{U}$ Taq polimerase beserta bufernya.

Amplifikasi DNA dengan PCR pada penelitian ini menggunakan mesin GeneAmp ${ }^{\mathrm{R}} \mathrm{PCR}$ system 2400 (Perkin Elmer). Amplifikasi gen COX 2 dilakukan dengan kondisi sebagai berikut: denaturasi awal selama 5 menit pada suhu $94^{\circ} \mathrm{C}$ selanjutnya diikuti dengan $94^{\circ} \mathrm{C}$ selama 30 detik untuk denaturasi, $50-60^{\circ} \mathrm{C}$ selama 45 detik untuk penempelan primer (annealing), $72^{\circ} \mathrm{C}$ selama 1 menit untuk pemanjangan (elongation); amplifikasi dilakukan sebanyak 35 siklus kemudian diakhiri 5 menit pada $72^{\circ} \mathrm{C}$.

Produk PCR dideteksi dengan cara dimigrasikan pada gel agarosa $1,2 \%$ dengan menggunakan buffer 1xTBE dalam peranti Submarine Electrophoresis (Hoefer, USA). Pengamatan dilakukan dengan bantuan sinar UV $(\lambda=300 \mathrm{~nm})$ setelah gel diwarnai dengan cybersave (Invitrogen). Penanda DNA dengan ukuran $100 \mathrm{pb}$ digunakan sebagai penunjuk berat molekul.

\section{Sekuensing DNA}

Produk PCR hasil amplifikasi dimurnikan menggunakan GFX Column purification kit (Amersham, USA). Selanjutnya, dipergunakan sebagai DNA cetakan untuk reaksi sekuensing DNA. Kondisi untuk reaksi sekuensing adalah: denaturasi awal selama 5 menit pada suhu $94^{\circ} \mathrm{C}$ selanjutnya diikuti dengan $94^{\circ} \mathrm{C}$ selama 30 detik, 50-60 ${ }^{\circ} \mathrm{C}$ selama 45 detik, $72^{\circ} \mathrm{C}$ selama 1 menit; reaksi amplifikasi sebanyak 35 siklus kemudian diakhiri dengan penambahan (extension) selama 5 menit pada $72^{\circ} \mathrm{C}$.

Produk reaksi sekuensing dipurifikasi menggunakan kolom autoseq G-50, kemudian DNA dikonsentrasikan dengan penambahan alkohol absolut yang dilanjutkan pencucian menggunakan alkohol 70\%. Setelah kering, ditambahkan ke dalamnya $6 \mu \mathrm{l}$ stop solution. Larutan diinkubasi pada $72^{\circ} \mathrm{C}$ selama 5 menit, kemudian dimasukkan ke dalam es. Sekuensing DNA menggunakan alat sekuensing DNA otomatis ABI Prism.4.1

\section{Analisis Data}

Data sekuen DNA dari gen COX2 hasil sekuensing dan sekuen DNA yang diperoleh dari data bases Internasional disejajarkan (alignment) dengan perangkat lunak program Clustal W (Thompson et al., 1994). Selain berdasarkan sekuen nukleotida, gen COX2 dianalisis berdasarkan urutan asam amino dari basa-basa yang diterjemahkan mengikuti vertebrate mitochondrial translation code yang ada dalam 
MEGA versi 4.1. Urutan asam amino sinonimus dianalisis secara manual berdasarkan sekuen triplet kodon yang mengalami mutasi.

\section{Hasil dan Pembahasan}

Ketiga pasang primer pada penelitian ini didesain untuk mengamplifikasi daerah gen COX2. Produk PCR hasil amplifikasi menggunakan primer $\mathrm{COX} 2 \mathrm{~F}$ dan $\mathrm{COX} 2 \mathrm{R}$ adalah sekitar 660 pb. Hasil PCR yang dimigrasikan pada gel agarosa $1,2 \%$ dan diwarnai dengan cyber save (Invitrogen) dapat dilihat pada Gambar 2.

Produk PCR hasil amplifikasi menggunakan primer COX2F dan COX2Rin adalah sekitar $375 \mathrm{pb}$ dan produk PCR hasil amplifikasi menggunakan primer COX2Fin dan
COX2R adalah sekitar 365 pb. Hasil PCR yang dimigrasikan pada gel agarosa $1,2 \%$ yang diwarnai dengan cybersave (Gambar 3). Pada penelitian ini digunakan 3 pasang primer, yaitu COX2F dengan COX2R (untuk sampel $T$. bancanus); COX2F dengan COX2Rin dan COX2Fin dengan COX2R (untuk sampel $T$. spectrum dan $T$. dianae) yang berturut-turut menghasilkan produk PCR sebesar 660 pb, 365 pb dan 375 pb. Hal ini disebabkan oleh kondisi DNA $T$. bancanus yang bagus sehingga dapat diamplifikasi pada panjang $660 \mathrm{pb}$, sedangkan kondisi DNA $T$. spectrum dan T.dianae yang kemungkinan sudah terfragmentasi sehingga hanya dapat diamplifikasi pada fragmen DNA yang ukurannya lebih pendek yaitu 365 pb dan $375 \mathrm{pb}$.

Tabel 1. Primer untuk amplifikasi gen $C O X 2$ pada Tarsius sp.

\begin{tabular}{|c|c|c|c|c|}
\hline Target & $\mathbf{R} / \mathbf{F}$ & Urutan Basa & Jml basa & Tm \\
\hline $660 \mathrm{bp}$ & $\overline{\mathrm{F}}$ & $\begin{array}{ll}5^{\prime} & \text { ACCCCTGTGTATTTTCATGGC } 3\end{array}$ & 21 & $\overline{57,59^{\circ} \mathrm{C}}$ \\
\hline & $\mathrm{R}$ & 5' ACTAGTTCTAGGACGATGGGCA 3' & 21 & $57,59^{\circ} \mathrm{C}$ \\
\hline 375 bp & $\mathrm{F}$ & 5' ACCCCTGTGTATTTTCATGGC 3' & 21 & $57,59^{\circ} \mathrm{C}$ \\
\hline & Rin & 5' TTAGGTCCTCATAGTCCGTAT 3' & 21 & $58,7^{\circ} \mathrm{C}$ \\
\hline $365 \mathrm{bp}$ & $\begin{array}{c}\text { Fin } \\
\mathrm{R}\end{array}$ & 5, CATCCCTAACTGTTAAGACCA 3, & 21 & $\begin{array}{r}58,7^{\circ} \mathrm{C} \\
57,50^{\circ} \mathrm{C}\end{array}$ \\
\hline
\end{tabular}

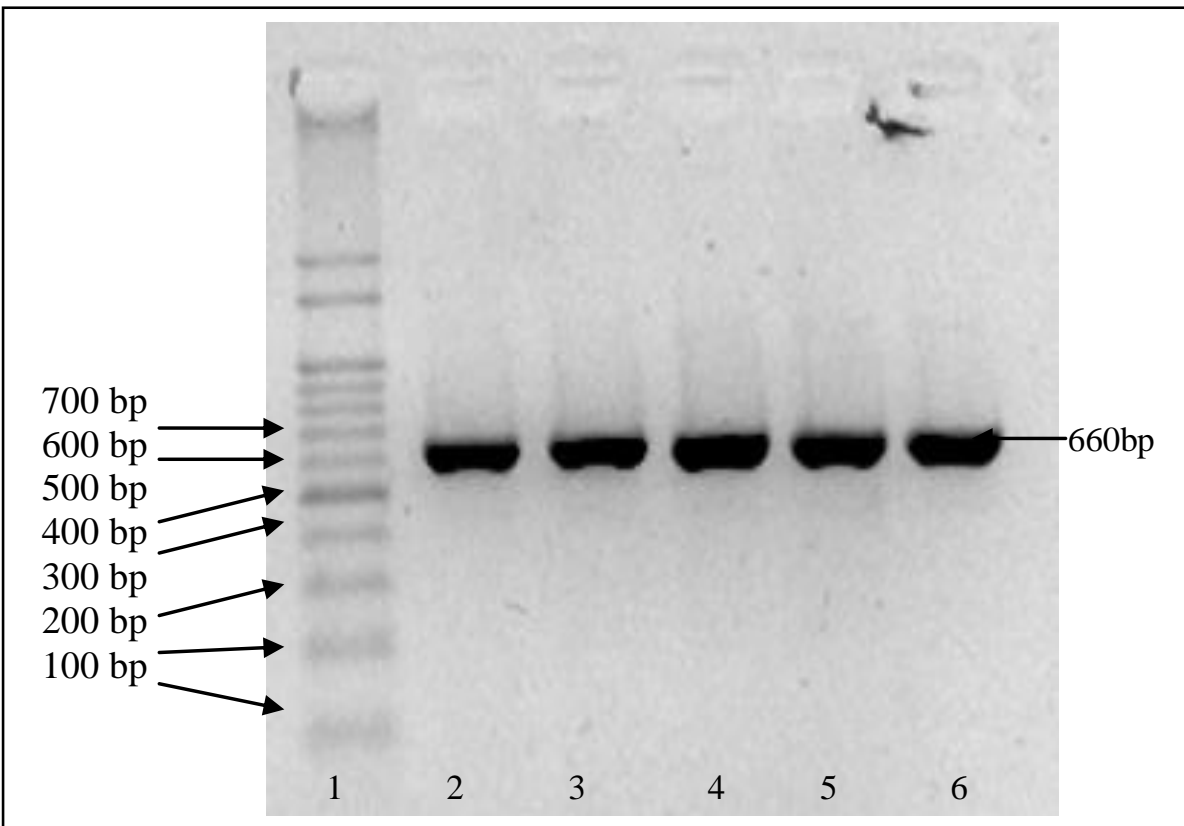

Gambar 2. Hasil PCR gen COX2 Tarsius bancanus menggunakan primer COX2F dan COX2R pada gel agarose $1,2 \%$.

Keterangan: 1. DNA ladder 100 bp (RBC), 2-6 produk PCR T. bancanus dengan ukuran $\pm 660 \mathrm{bp}$. 
Kejadian fragmentasi DNA pada $T$. spectrum dan $T$. dianae disebabkan oleh kerusakan jaringan pada saat pengambilan sampel. Hal ini karena lokasi pengambilan sampel yang jauh dari lokasi penelitian sehingga terjadi kerusakan saat diperjalanan. Sampel DNA yang digunakan pada penelitian ini adalah DNA mitokondria bukannya DNA inti yang terselubung oleh protein histon sehingga kemungkinan untuk terdegradasi bagi DNA mitokondria adalah sangat besar (Nelson dan Cox, 2006).
Berdasarkan sekuen genom mt-DNA $T$. bancanus (Schmitz et al., 2002) fragmen DNA pada penelitian ini terletak pada gen $t \mathrm{RNA}^{\text {Asp }}$ (basa ke-45 dari ujung 5' gen $t \mathrm{RNA}^{\mathrm{Asp}}$ ) sampai pada basa ke-643 dalam gen COX2. Besarnya fragmen DNA yang teramplifikasi pada penelitian ini setelah diplotkan dengan data sekuen DNA mitokondria $T$. bancanus hasil penelitian Schmitz et al., (2002) adalah 660 pb, yaitu terdiri dari $16 \mathrm{pb}$ fragmen gen $t \mathrm{RNA}^{\mathrm{Asp}}$ dan $644 \mathrm{pb}$ fragmen gen COX2. Skema letak penempelan primer untuk mengamplifikasi gen COX2 dapat dilihat pada Gambar 4.

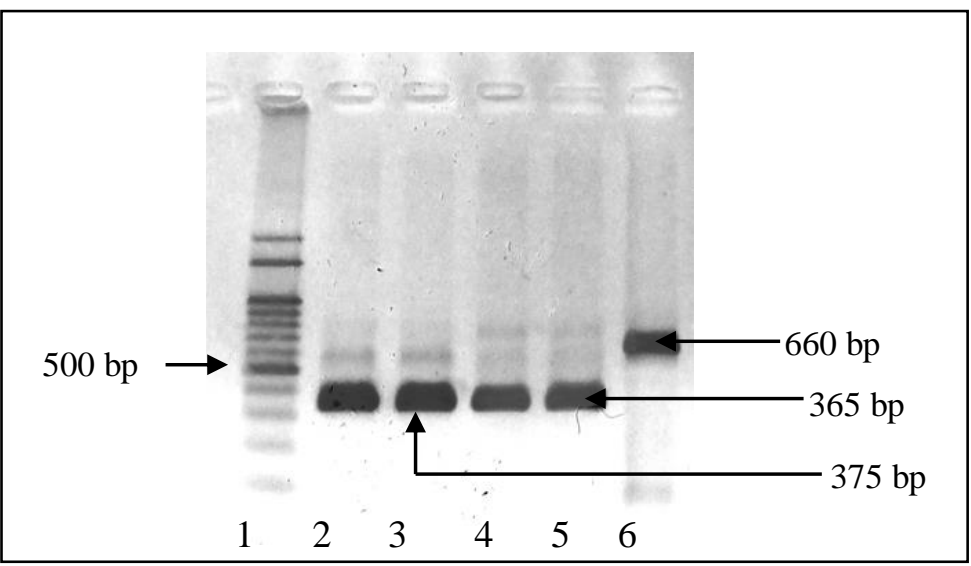

Gambar 3. Hasil PCR gen COX2 Tarsius sp. menggunakan primer COX2F-COX2R;COX2F-COX2Rin;COX2Fin-COX2R pada gel agarose $1,2 \%$.

Keterangan: 1. DNA ladder $100 \mathrm{bp}$ (RBC), 2-3 produk PCR dengan primer COX2F-COX2Rin T. spectrum, T. dianae, 4-5 produk PCR dengan primer COX2Fin-COX2R T.spectrum, T. dianae, 6 produk PCR T. bancanus dengan primer COX2F-COX2R.

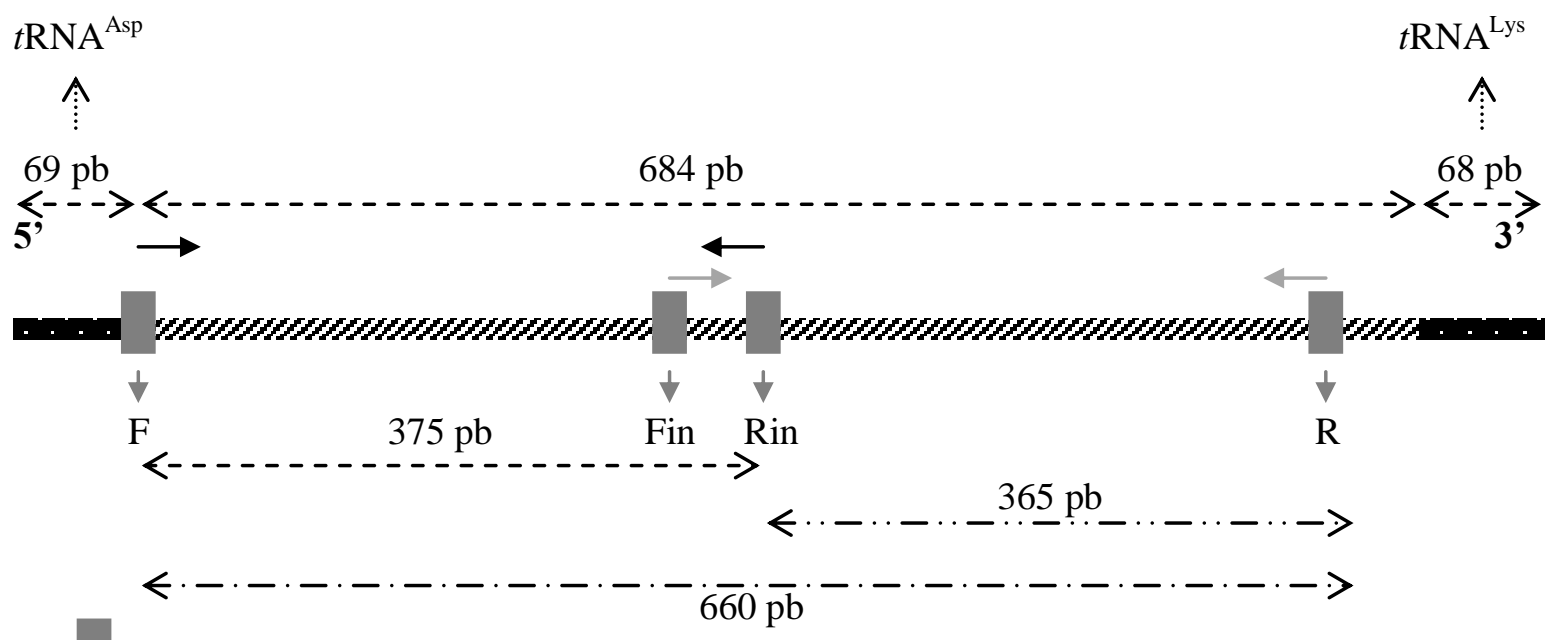

Primer

Gambar 4. Skema letak penempelan primer COX2F, COX2Fin, COX2Rin dan COX2R untuk mengamplifikasi daerah gen $C O X 2$ pada Tarsius sp. 
Analisis keragaman nukleotida dilakukan setelah semua sekuen DNA hasil penelitian dan primata spesies lain yang diambil dari Genbank disejajarkan berganda (multiple alignment). Fragmen DNA COX2 parsial sepanjang 660 nukleotida (nt) setelah dilakukan penentuan sekuen (sekuensing) diperoleh 513 nt yang dapat dianalisis, yaitu pada posisi ke-127 sampai dengan posisi ke 639 dari ujung 5' gen COX2 utuh (disajikan pada Gambar 5). Lima ratus tiga belas basa nukleotida ini menyandi 171 asam amino, dan hasil penjajaran ke 171 asam amino pada Tarsius $s p$. hasil penelitian dengan pembanding $T$. bancanus (Schmitz et al., 2002) berada pada posisi asam amino ke-43 sampai dengan ke 213 dari ujung 5' gen COX2 utuh.

Hasil penjajaran berganda sekuen nukleotida gen $C O X 2$ parsial semua sampel Tarsius pada penelitian ini tidak terjadi insersi dan delesi sehingga ukurannya tetap sama. Demikian juga terhadap DNA primata lain yang digunakan sebagai pembanding. Perubahan yang terjadi adalah substitusi. Hasil perbandingan ke513 nukleotida Tarsius dengan $T$. bancanus pembanding (Schmitz et al., 2002), sebanyak 51 nukleotida dikategorikan sebagai situs beragam dan berdasar sekuen asam amino ditemukan 11 situs asam amino yang beragam.

Diantara sampel-sampel Tarsius pada penelitian ini (tanpa pembanding) ditemukan 33 situs nukleotida beragam (28 situs kodon beragam) dan 8 situs asam amino beragam. Ke delapan situs asam amino tersebut dapat untuk membedakan $T$. bancanus dengan $T$. spectrum dan T.dianae, yaitu urutan asam amino ke 5 ( $\mathrm{T}$ dengan $\mathrm{S}$ ), 6 (T dengan $\mathrm{S}$ ), 13 (T dengan $\mathrm{A}$ ), 14 (M dengan $\mathrm{V}$ ), 30(I dengan $\mathrm{F}$ ), 35(A dengan $\mathrm{V}$ ),
44 ( $\mathrm{L}$ dengan $\mathrm{M}$ ), dan 168 (V dengan A). Tarsius spectrum dan $T$. dianae pada penelitian ini tidak ditemukan perbedaan pada tingkat asam amino maupun nukleotida.

Seratus tujuh puluh satu asam amino pada penelitian ini, ditemukan 143 asam amino kekal (nukleotidanya tidak mengalami substitusi), 20 asam amino bersifat sinonimus (nukleotida mengalami substitusi tetapi asam aminonya tetap) dan 8 asam amino bersifat non sinonimus (nukleotida berubah dan asam aminonya berubah).

Jarak genetik berdasar sekuen nukleotida gen COX2 parsial (513 nt) Tarsius pada penelitian ini paling kecil $0 \%$, yaitu antara $T$. spectrum dan $T$. dianae; $T$. bancanus 5 dan $T$. bancanus3; T.bancanus1 dan T. bancanus 2 , dan nilai paling besar $6,8 \%$ yaitu antara $T$. spectrum dan $T$. bancanus4 serta antara $T$. dianae dan $T$. bancanus4. Jarak genetik keseluruhan berdasarkan nukleotida pada penelitian ini adalah $4,03 \%$.

Jarak genetik Tarsius sp. pada gen COX2 (4,03\%), sedangkan jarak genetik pada gen $C y t b$ $(13,1 \%)$ (Widayanti et al., 2006), jarak genetik pada gen ND3 adalah $0,01 \%$ (Widayanti et al., 2010) dan jarak genetik pada daerah $D$-loop (2,3\%) (Widayanti dan Solihin, 2007). Dari keempat sekuen fragmen DNA ini yang paling baik digunakan sebagai penanda genetik adalah gen $C y t b$, walaupun pada tingkat asam amino gen $C y t \quad b$ tersebut kurang memberikan hasil yang memuaskan. Oleh karena itu, masih perlu dilakukan penelitian pada gen-gen lain yang dapat digunakan sebagai penanda genetik spesies-spesies Tarsius.
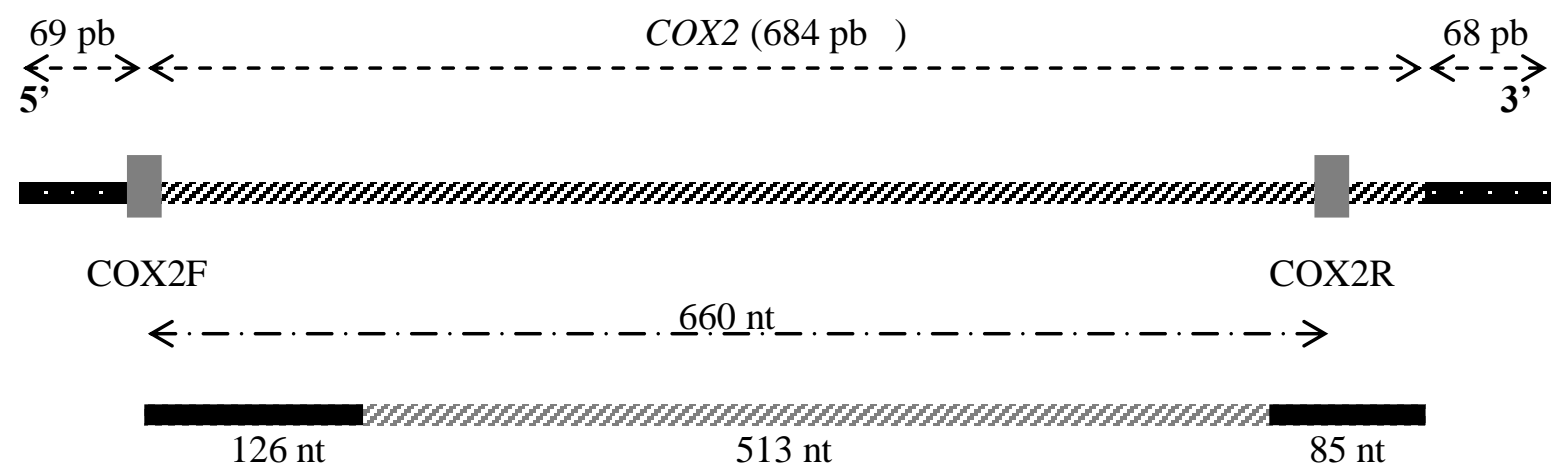

Gambar 5. Skema gen COX2 dan sebagian daerah hasil sekuensing DNA (berukuran $513 \mathrm{nt}$ ) yang digunakan untuk analisis keragaman genetik pada Tarsius $s p$. 
Analisis filogenetik pada penelitian ini menggunakan metode Neighbor Joining dilakukan terhadap 513 nukleotida yang menyusun gen COX2 parsial dengan spesies primata lain yang diambil dari Genbank sebagai pembanding. Gambar 6 menyajikan filogram berdasar sekuen nukleotida gen COX2 parsial. Filogram yang dihasilkan terlihat bahwa $T$. spectrum dan $T$. dianae berada dalam satu cabang (asal Sulawesi), sedangkan T. bancanus (asal Lampung) membentuk cabang tersendiri. Pemisahan ini didukung oleh nilai "bootstrap" yang tinggi (100\%). Pemisahan yang sama juga ditunjukkan oleh filogram hasil analisis asam amino COX2 parsial (Gambar 7). Hal ini disebabkan oleh tidak adanya perbedaan nukleotida antara Tarsius asal Sulawesi, yaitu $T$. spectrum dan $T$. dianae.

Filogram berdasar sekuen gen ND3 dan $D$-loop menempatkan $T$. spectrum (asal Sulawesi Utara), $T$. dianae (asal Sulawesi Tengah), dan $T$. bancanus (asal Lampung) berada dalam satu cabang. Pola filogram tersebut menunjukkan bahwa hasil yang didapat berbeda dengan pembagian spesies tarsius berdasar morfologi dan vokalisasi (Musser dan Dagosto 1987 dan Niemitz et al., 1991). Pola filogram yang dapat membedakan ketiga spesies Tarsius tersebut yang sesuai dengan pembagian spesies Tarsius berdasarkan morfologi dan vokalisasi hanya yang berdasarkan nukleotida dan asam amino $c y t$ $b$.

Berdasarkan morfologi, sampai saat ini Tarsius masih menjadi perdebatan apakah masuk subordo Strepsirrhini (dahulu prosimian, kelompok primata kecil) atau intermedier (dipertengahan) antara subordo Haplorrhini (dahulu anthropoidea, kelompok primata besar) dan prosimian, karena menunjukkan ciri-ciri diantara keduanya. Ciri-ciri yang sama dengan prosimian adalah yaitu nocturnal, mata besar, telinga dapat digerakkan, mempunyai "toilet claw" pada jari kaki kedua dan ketiga, serta mandibula tersusun dari dua tulang. Ciri-ciri yang sama dengan anthropoidea adalah tanpa rhinarium telanjang, tanpa "dental comb", cermin hidung kering, gigi seri bawah menghadap ke atas, dan plasenta hemochorial (Napier dan Napier, 1983). Demikian juga hasil yang diperoleh pada penelitian ini, filogram berdasar pada urutan nukleotida dan asam amino COX2 menempatkan Tarsius sp. ke dalam subordo prosimian. Hasil ini sama dengan pengelompokan berdasarkan sekuen nukleotida dan asam amino gen $C y t b$ (Widayanti, 2006) dan ND3 (Widayanti dkk., 2010). Hasil yang menunjukkan bahwa Tarsius sp. berada di pertengahan (intermedier) antara subordo Strepsirrhini dan subordo Haplorrhini hanya berdasarkan sekuen nukleotida D-loop (Widayanti et al., 2007).

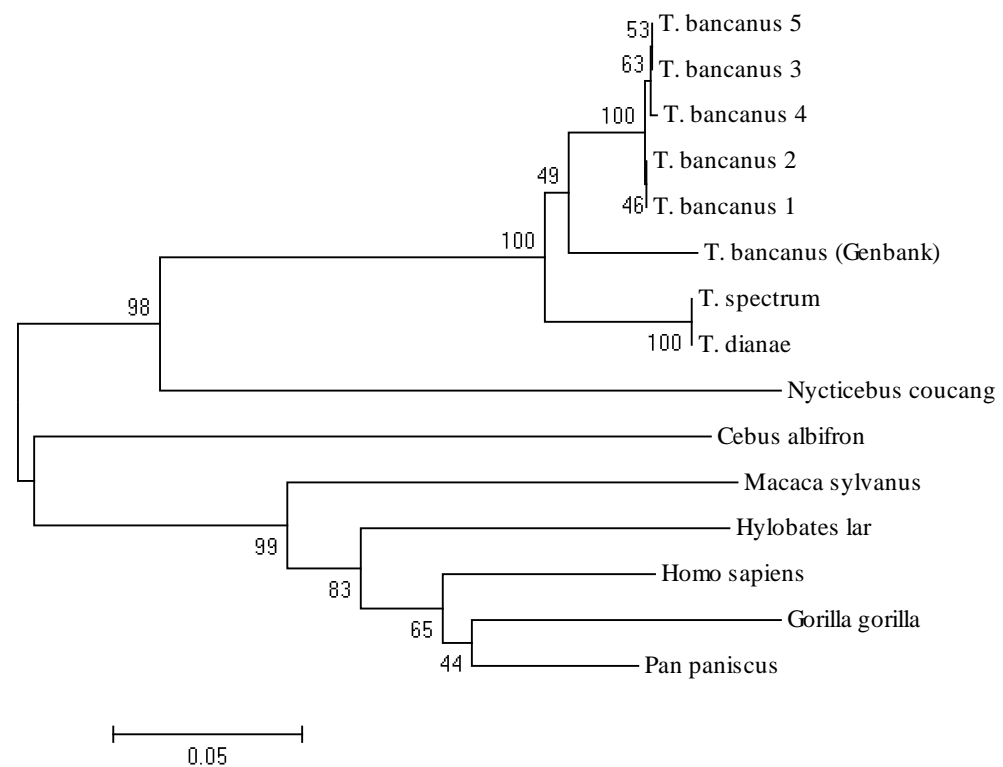

Gambar 6. Filogram menggunakan metode Neighbor joining dari nukleotida daerah gen COX2 parsial (berukuran $513 \mathrm{nt}$ ) Tarsius $s p$. dan beberapa spesies primata lain. 


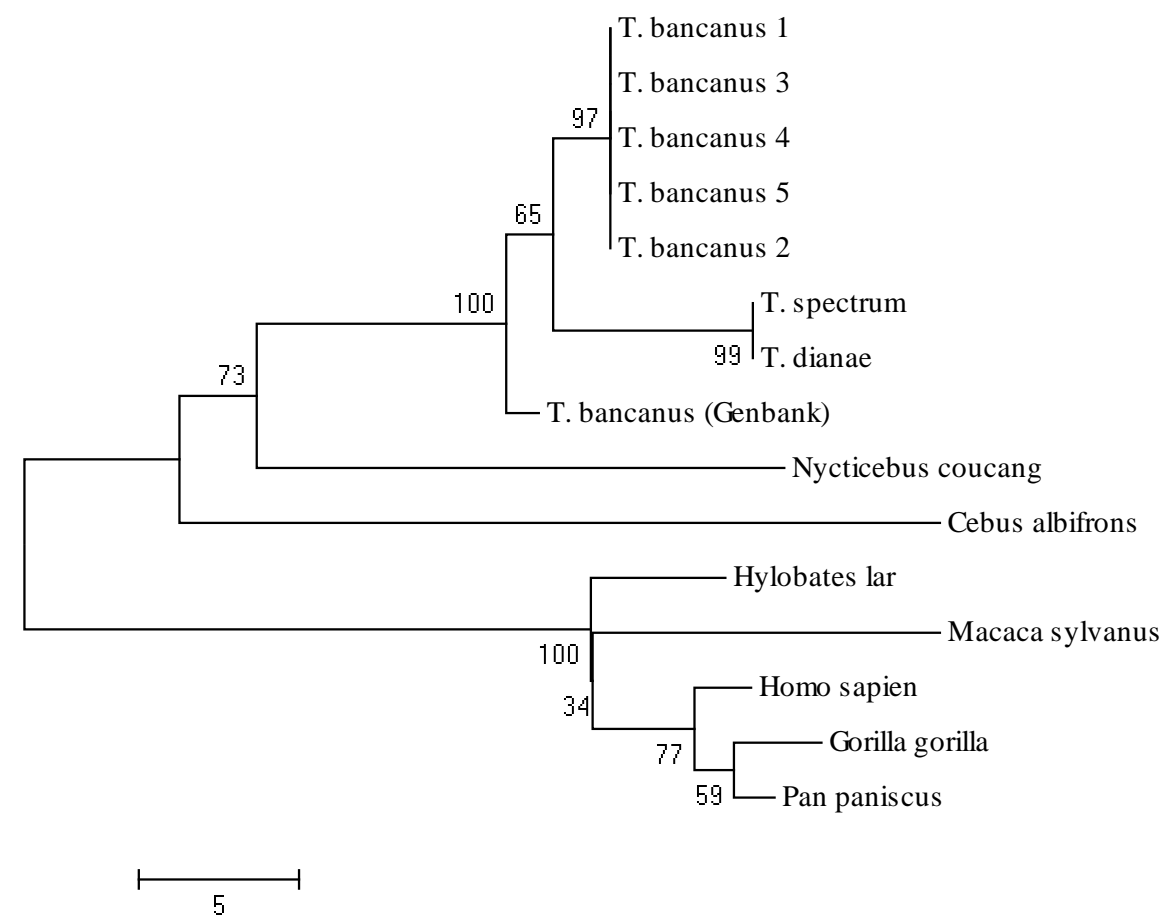

Gambar 7. Filogram menggunakan metode Neighbor joining dari asam amino daerah gen COX2 parsial (berukuran 171 asam amino) Tarsius $s p$. dan beberapa spesies primata lain.

\section{Simpulan dan Saran}

\section{Simpulan}

Jarak genetik antara $T$. spectrum dan T.dianae sangat dekat $(0,0 \%)$, dan jarak genetik antara $T$. bancanus dengan $T$. spectrum dan $T$. dianae adalah $6,8 \%$. Sekuen nukleotida dan asam amino gen COX2 dapat untuk membedakan $T$. bancanus dengan $T$. dianae dan $T$. spectrum, tetapi tidak dapat untuk membedakan $T$. spectrum dengan $T$. dianae. Sekuen gen COX2 dapat digunakan untuk mengelompokkan Tarsius ke dalam kelompok subordo Strepsirrhini.

\section{Saran}

Perlu penelitian lanjutan pada gen-gen lainnya sehingga didapatkan penanda genetik untuk identifikasi spesies-spesies Tarsius.

\section{Ucapan Terima Kasih}

Ucapan terima kasih penulis sampaikan kepada DIKTI melalui proyek Hibah Bersaing XVI Perguruan Tinggi tahun 2008 yang telah memberi dukungan dana untuk penelitian ini. Juga, kepada saudara Susi yang telah membantu untuk mendapatkan sampel penelitian.

\section{Daftar Pustaka}

Galina, V., Glazko dan Nei, M. 2003. Estimation of Divergence Times for Major Lineages of Primate Species. Mol. Biol. Evol, 20 (3): 424-434.

Groves, C. 2001. Primate Taxonomy. London:Smithsonian Inst Pr. Pp: 121-125.

Kumar, S., Tamura, K., Jakobsen, I.B. dan Nei, M. 2001. Molecular Evolutionary Genetics Analysis Version 2.0. Pennsylvania State Univ.: Inst of Molecular Evolutionary genetics.

Majerus, M., Amos, W. dan Hurst, G. 1996. Evolution: The Four Bilion Year War. Malaysia: Longman: 198-203, 213.

Merker, S. 2003. Endangered or Adaptable? The Dian's Tarsier Tarsius Dianae in Sulawesi's rainforests. Dissertation. Univ Gottingen. [Abstrak].

Musser, G.G. dan Dagosto, M. 1987. The Identity of Tarsius pumilus, a Pygmy Species Endemic to the Montane Mossy of Central Sulawesi. Am. Museum. Novitates, 2867: 1-53. 
Nelson, D.L. dan Cox, M.M.2006. Lehninger Principles of Biochemistry. University of WisconsinMadison. $4^{\text {th }}$ Ed. Pp. 949-951.

Schmitz, J., Ohme, M. dan Zischler, H. 2000. The Complete Mitochondrial Genome of Tupaia belangeri and the Phylogenetic Affilation of Scandentia to Other Eutherian Orders. Mol. Boil. Evol, 17: 1334-1343.

Schmitz, J., Ohme, M. dan Zischler, H. 2002. The Complete Mitochondrial Sequence of Tarsius bancanus: Evidence for an Extensive Nucleotide Compositional Plasticity of Primate Mitochondrial DNA. Mol. Biol. Evol, 19: 544-553.

Shekelle, M. 2003. Taxonomy and Biogeography of Eastern Tarsiers. Doctoral thesis. St. Louis: Washington Univ.

Shekelle, M. dan Leksono, S.M. 2004. Strategi Konservasi di Pulau Sulawesi dengan Menggunakan Tarsius Sebagai Flagship Species. Biota, 9 (1): $1-10$.

Shekelle, M. 2008. The History and Mystery of the Mountain Tarsier, Tarsius pumilus. Primate Conservation, 23: 121-124.

Shimada, M.K. 2004. Mitochondrial DNA Genealogy of Chimpanzees in the Nimba Mountains and Bossou, West Africa. Am. J. Primatol, 64: 261-275.
Supriatna dan wahyono, E.H. 2000. Primata Indonesia: Obor Indonesia. Panduan Lapangan.

Thompson, J.D., Higgins, D.G. dan Gibson, T.J. 1994. CLUSTAL W: Improving the Sensitivity of Progressive Multiple Sequence Alignment Through Sequence Weighting, Position-specific Gap Penalties and Weight Matrix Choice. Nucleic Acid Res, 22: 4673-4680.

Wetz, D.C. 2000. The DNA Ancestree. Geneletter 1 (8). http://www.geneletter.rg/09-01-00/features/ sncestrrea.html. 08/18/2004.

Widayanti, R., Solihin, D.D., Sajuthi, D. dan Perwita, D. 2006. Kajian Penanda Genetik Gen Cytochrome B pada Tarsius sp. J. Sain. Vet, 24 (1): 1-8.

Widayanti, R. dan Solihin, D.D. 2007. Kajian Penanda Genetik Tarsius bancanus dan Tarsius spectrum dengan Sekuen D-Loop Parsial dari DNA Mitokondria. Biota, 12 (3): 172-178.

Widayanti, R., Handayani, N.S.H. dan Budiarsa, I.M. 2010. Kajian Keragaman Genetik Gen Penyandi Dehydrogenase Sub-unit 3 (ND3) Mitokondria pada Tarsius sp.: Upaya Konservasi Tarsius sp. J. Veteriner (in press). 